\title{
PENGARUH METODA PENYIMPANAN TERHADAP VIABILITAS DAN VIGOR BENIH CALOPO (Calopogonium mucunoides)
}

\author{
Sajimin ${ }^{1}$, A. Fanindi ${ }^{1}$, dan R. Hutasoit ${ }^{2}$ \\ ${ }^{1}$ Balai Penelitian Ternak, Jl. Veteran III Banjarwaru Ciawi-Bogor \\ ${ }^{2}$ Loka Kambing Potong Sei Putih \\ Email:djiemin@yahoo.com
}

\begin{abstract}
ABSTRAK
Calopo (Calopogonium mucunoides) termasuk tanaman penutup tanah yang banyak digunakan di perkebunan di Indonesia. Penelitian ini bertujuan untuk mempelajari kualitas dengan mempelajari daya kecambah benih dengan perbedaan waktu simpan dan perbedaan tempat penyimpan benih. Penelitian dilakukan di laboratorium benih Agrostologi Balai Penelitian Ternak Ciawi-Bogor. Rancangan percobaan acak lengkap dengan perlakuan waktu penyimpanan 1, 2, 3, 4, 5, 6, 7, 8, 9, 10 dan 11 bulan pada tempat penyimpanan yang berbeda yaitu kantang kertas semen, aluminium foil dan kotak plastik. Sebanyak $1 \mathrm{~kg}$ benih disimpan sesuai perlakuan di dalam suhu kamar. Kualitas benih dilakukan uji daya kecambah sebanyak 150 biji dibersihkan kemudian diletakan pada petri dish yang berisi 50 biji. Pengamatan dilakukan setiap hari selama 21 hari. Hasil penelitian mengindikasikan penyimpanan semakin lama benih disimpan maka kualitas benih menurun dengan daya kecambahnya semakin rendah. Benih disimpan selama 1 bulan sampai 6 bulan daya kecambahnya 75-84\% kemudian penyimpanan 7-11 bulan menurun dengan daya kecambah kurang dari $58,0 \%$. Tempat penyimpanan benih calopo terbaik pada aluminium foil kemudian dikuti dalam kantong kertas semen dan terendah pada kotak plastik.
\end{abstract}

Kata kunci: kualitas benih, Calopogonium mucunoides, waktu penyimpanan, tempat simpan.

\section{PENDAHULUAN}

Luas perkebunan karet di Indonesia mencapai 3.621.587 ha kemudian tanaman sawit 11.300.370 ha (Statistik, 2015). Peremajaan tanaman perkebunan tiap tahun mencapai 56.000 hektar karet rakyat diremajakan (Karyudidan Siagian, 2005). Peremajaan tanaman kebun sebelum menghasilkan (TBM) memerlukan tanaman penutup tanah yang berfungsi penyubur tanah dan merupakan standar baku teknis.

Tanaman penutup tanah yang umum digunakan adalah LCC (leguminosa cover crop) jenis Pueraria javanica, calopo dan centrosema yang telah terbukti berdampak positif tapi belum berkembang. Tanaman penutup tanah yang tidak berkembang disebabkan kesulitan mendapatkan bahan tanam dalam skala besar. Kebutuhan benih menurut Sumarmaji (2005) mencapai16oo ton/tahun jenis P.javanica. Namun produksi dalam negeri yang masih terbatas dan belum ada penangkar benih yang bersertifikat dengan jaminan mutu. Benih yang ada dipasaran daya kecambah sangat rendah (dibawah $40 \%$ ) (Karyudi dan Siagian, 2005). Sehingga untuk pemenuhan benih perkebunan selalu impor dengan harga yang mahal.

Penelitian pasca panen benih tanaman pakan ternak penting untuk dilakukan mengingat bahwa baik-buruknya tanaman sangat tergantung antara lain pada mutu benih yang ditanam. Menurut Sadjad et al. (2001) benih-benih varietas tanaman yang dikomersialkan harus memiliki mutu genetik yang lebih baik dari pada benih varietas-varietas yang sudah beredar. Paling tidak, ada satu cirri yang bias ditonjolkan sebagai suatu kelebihan dibandingkan dengan yang sudah diedarkan (seperti vigor atau keseragaman bentuk yang lebih homogen).

Penelitian tanaman pakan ternak yang mengarah ke peningkatan produksi biji, prosesing, penyimpanan dan pengendalian mutu benih untuk mendapatkan benih bermutu tinggi baik bagi penangkar benih maupun untuk pengguna sudah dilaksanakan di Balitnak sejak tahun 2001, namun penelitian itu terbatas pada beberapa spesies leguminosa saja.

Hasil biji tanaman pakan ternak yang tinggi tidak banyak artinya apabila tidakdidukung dengan penyimpanan yang baik. Dalam penyimpanan benih perlu diperhatikan beberapa faktor, yaitu (1) penyimpanan di lapang, (2) penyimpanan setelah panen sampai sesaat sebelum pengolahan, (3) penyimpanan sejak benih dikeringkan sampai menunggu penyaluran, (4) penyimpanan selama penyaluran, dan (5) penyimpanan benih oleh konsumen. Selain itu metode penyimpanan benih yang baik harus mempertimbangkan kondisi ruangan, kemasan, dan manajemen pengontrolan mutu.

Salah satu alternatif untuk mengurangi ketergantungan benih tanaman penutup tanah perlu upaya 
peningkatan produksi benih dalam negeri dengan teknologi penyimpanan.Tulisan ini mengemukakan hasil pengamatan kualitas benih calopo dalam berbagai waktu simpan dengan kemasan berbeda.

\section{MATERI DAN METODA}

\section{Tempat dan waktu penelitian}

Penelitian ini dilakukan di laboratorium benih Agrostologi dan di rumah kaca Balitnak Ciawi-Bogor. Percobaan dilakukan Pengaruh lama penyimpanan dan pengaruh metode penyimpanan dalam berbagai kemasan untukmelihat daya simpannya.

\section{Bahan dan alat}

Penelitian menggunakan benih Calopogonium mucunoides diperoleh dari hasil penelitian di kebun percobaan yang telah terseleksi kemudian perlakuan penyimpanan. Wadah yang digunakan penyimpanan dari kantong aluminum foil, kantong kertas semen yang masing-masing berukuran panjang $30 \mathrm{~cm}$ dan lebar $20 \mathrm{~cm}$, dan container plastic (stoples) berukuran tinggi $10 \mathrm{~cm}$, lebar $12 \mathrm{~cm}$ dan panjang $25 \mathrm{~cm}$ (volume $1 \mathrm{~kg}$ benih), germinator, petridish, pinset, pinsil, dan buku tulis.

Rancangan Percobaan ini menggunakan Rancangan acak lengkap dengan 3 perlakuan yaitu:

A = Penyimpanan dalam kantong aluminum foil,

$\mathrm{B}=$ Penyimpanan di dalam stoples plastik tertutup,

$\mathrm{C}=$ Penyimpanan dalam kantong semen.

Benih-benih kalopo yang telah dipanen dibersihkan dan dikeringkan mencapai kadar air rata14\% kemudian disimpan sesuai perlakuan dengan waktu penyimpanan 1, 2, 3, 4, 5, 6, 7, 8, 9, 10, dan11 bulan.

Kualitas benih hasil penyimpanan kemudian diamati daya kecambah (DB) dan viabilitasnya dengan mengambil sampel sebanyak 150 benih dicuci bersih kemudian diletakkan dalam 3 petridish masingmasing berisi 50 biji. Pengamatan daya kecambah dilakukan dari ke 1 sampai hari ke 15. Rumus yang digunakan adalah :

$$
D B=\frac{K N}{J B} \times 100 \%
$$

Dimana:

DB = Daya Kecambah

$\mathrm{KN}=$ Kecambah normal

$\mathrm{JB}=$ Jumlah benih

Kecepatan tumbuh $(\mathrm{KCT})=\sum$ d. Pengujian dilakukan dengan mengamati hasil kecambah normal yang muncul setiap hari hingga pengamatan kecambah hitungan terakhir.

\section{HASIL DANPEMBAHASAN}

Dari hasil percobaan ternyata bahwa benih C.mucunoides yang disimpan di dalam kontainer plastik memperlihatkan viabilitas dan vigor terbaik pada umur penyimpanan dari 1 bulan - 6 bulan. Kemudian diikuti perlakuan penyimpanan kantong aluminum foil dan terendah kantong kertas semen.

Tabel 1. Daya Kecambah Calopo mucunoides Setelah Disimpan 1 -11 Bulan

\begin{tabular}{|c|c|c|c|}
\hline \multirow{2}{*}{$\begin{array}{c}\text { Waktu } \\
\text { Penyimpanan } \\
\text { (bulan) }\end{array}$} & \multicolumn{3}{|c|}{ Daya Kecambah (\%) } \\
\hline & $\begin{array}{c}\text { Kantong kertas } \\
\text { semen }\end{array}$ & $\begin{array}{c}\text { Kantong } \\
\text { aluminium foil }\end{array}$ & Kontainer plastik \\
\hline 1 & $86,68^{a}$ & $89,00^{a}$ & $69,33^{b}$ \\
\hline 2 & $82,04^{b}$ & $84,67^{b}$ & $93,33^{a}$ \\
\hline 3 & $76,78^{b}$ & $83,33^{a}$ & $86,00^{a}$ \\
\hline 4 & $69,33^{b}$ & $75,00^{b}$ & $86,00^{a}$ \\
\hline 5 & $58,00^{b}$ & $75,33^{a}$ & $74,67^{a}$ \\
\hline 6 & $78,00^{a}$ & $54,00^{b}$ & $70,00^{a}$ \\
\hline 7 & $38,00^{b}$ & $58,00^{a}$ & $52,00^{a}$ \\
\hline 8 & $27,33^{b}$ & $33,33^{b}$ & $47,33^{a}$ \\
\hline 9 & $20,60^{b}$ & $17,33^{b}$ & $26,00^{a}$ \\
\hline 10 & $24,67^{\mathrm{C}}$ & $54,67^{a}$ & $35,33^{b}$ \\
\hline 11 & $16,00^{b}$ & $27,33^{a b}$ & $34,67^{a}$ \\
\hline
\end{tabular}

Keterangan: Angka-angka yang diikuti oleh huruf sama dalam baris sama tidak berbeda nyata $\mathrm{P}<0,05$

Pada Tabel 1 terlihat penyimpanan benih pada berbagai kemasan semakin lama penyimpanan daya kecambah menurun dari $86.86 \%$ (penyimpanan 2 bulan) terus menurun menjadi 21,31\% (9 bulan). Penurunan daya kecambah diduga tempat penyimpan berpengaruh pada daya kecambah benih calopo. Jika dibandingkan jenis tempat penyimpanan rata-rata daya kecambah tertinggi pada container plastik, kemudian kantong aluminum dan terendah kantong kertas semen.

Pada Tabel 1 dan Gambar 1 terlihat bahwa daya kecambah benih calopo dengan semakin lama penyimpanan semua perlakuan menurun. Sedangkan pada penyimpanan kotainer plastik menunjukkan lebih tinggi daripada kertas semen dan aluminium foil. Hal ini disebabkan container plastik lebih kedap udara dan menjaga kelembaban udara sehingga tidak ada kadar air yang masuk dalam biji. Menurut Destiana, et al (2016) penggunaan jenis plastic untuk penyimpanan memperpanjang daya simpan benih yang berkualitas. Kemudian Dinarto (2010) wadah kantong plastik mampu melindungi benih dari pengaruh kelembaban udara sekitarnya dan menekan peningkatan kadar air benih daripada penyimpanan pada kantong terigu pada benih kedele.

Hasil penelitian daya kecambah benih calopo yang disimpan lebih 6 bulan terjadi penurunan menjadi kurang dari 50\%. Penurunan ini disebabkan benih mengalami kerusakan disebabkan benih disimpan 


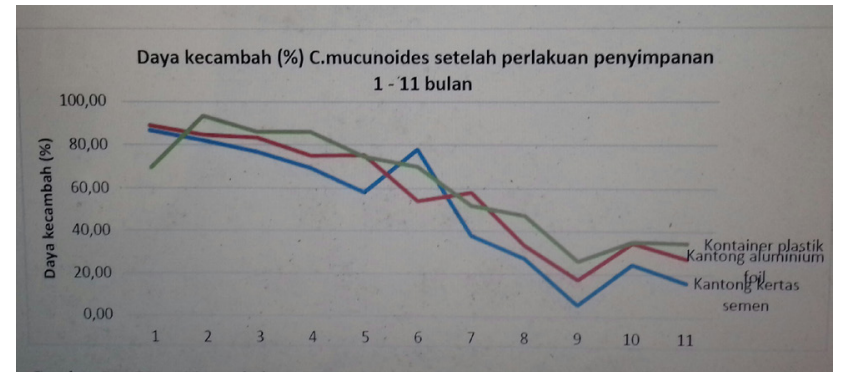

Gambar 1. Daya kecambah C.mucunoides selama penyimpanan 1-11 bulan pada 3 jenis penyimpanan.

pada ruang dengan kadar air tinggi atau kelembaban tinggi dan suhu ruang simpan tinggi. Menurut Dinarto (2010) kondisi tersebut mengakibatkan penurunan mutu benih baik secara kuantitatif maupun kulitatif. Hasil penelitian benih calopo yang disimpan hingga 11 bulan kerempakan daya kecambah tidak serempak seperti yang tertera pada Gambar 2.

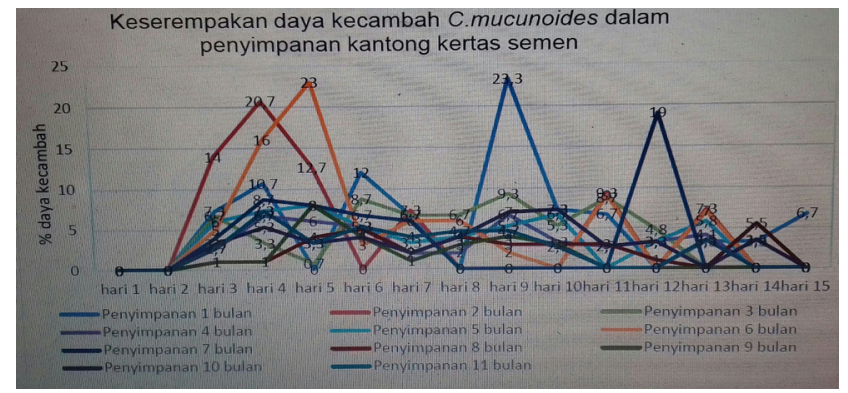

Gambar 2. Keserempakan daya kecambah C.mucunoides dalam penyimpanan kantongkertas semen.

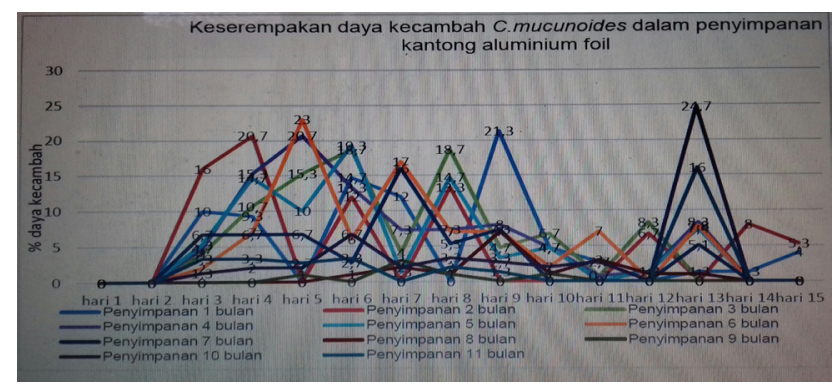

Gambar 3. Keserempakan Daya Kecambah C.mucunoides dalam Penyimpanan Kantong Aluminium Foil

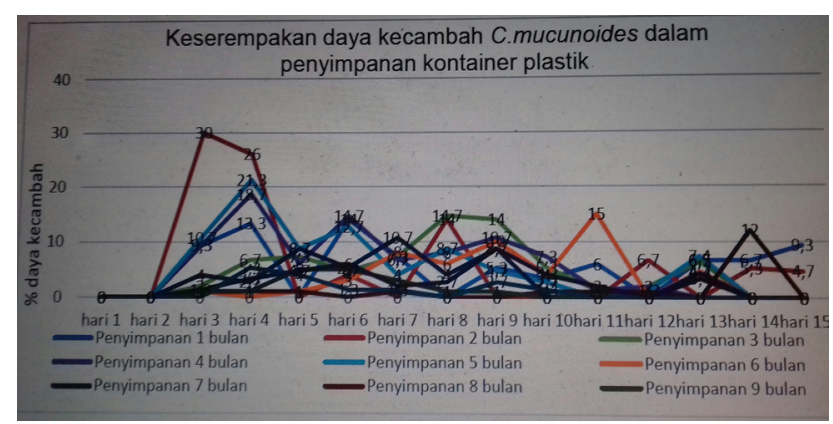

Gambar 4. Keserempakan Daya Kecambah C.mucunoides dalam Penyimpanan Kontainer Plastik

Hasil pengamatan terlihat tempat penyimpanan berpengaruh nyata terhadap viabilitas dan vigor benih kalopo pada pengamatan daya kecambah. Persentase kecambah tertinggi didapat pada perlakuan container plastik yaitu 93,3\% penyimpanan 2bulan. Kemudian pada kantong aluminium foil 89\% (masa simpan 1 bulan) dan kantong kertas semen $86,68 \%$ (masa simpan 1 bulan). Setelah bulan ke lima bulan semua daya kecambah telah menurun.

Daya kecambah terendah pada perlakuan kantong kertas semen 16,1\% yang telah disimpan 11 bulan. Begitu juga dengan perkecambahan benih kalopo pada uji keserempakan berkecambah angka tertinggi didapat pada hari ke 9 (23,3\%) pada benih disimpan 1 bulan.

Pada Gambar diatas terlihat bahwa daya kecambah benih dengan waktu simpan mempengaruhi. Hal ini diduga saat panen yang tidak seragam atau masak fisiologis akan mempengaruhi kualitas benih. Hal ini Menurut Hasanah dan Rusmin (2006) tingkat kemasakan biji tidak serentak sehingga pelaksanaan polong yang diambil disesuaikan kondisi tanaman yang secara visual masak fisiologis (warna polong crem) karena benih bermutu tinggi dapat diperoleh pada panen pada saat masak fisiologis yang akan mempunyai bobot dan vigor yang maksimum.

\section{KESIMPULAN}

Kualitas benih kalopo dipengaruhi oleh periode simpan dan jenis kemasan. Daya kecambah benih semakin lama disimpan pada suhu ruang kualitas semakin menurun seiring dengan bertambahnya waktu simpan. Penyimpanan 1- 5 bulan mencapai 75- $84 \%$ penyimpanan lebih 6 bulan daya kecambah menurun $58 \%$.

Kualitas benih kalopo dapat dipertahankan pada semua kemasan dalam waktu simpan sampai 5 bulan dan setelah itu kualitas benih telah menurun

\section{REFERENSI}

Arsyad, A., R.Y, Farnidan dan Ermadani. 2011. Aplikasi pupuk hijau (Calopogonium mucunoides dan Pueraria javanica) terhadap air tanah tersedia dan hasil kedelai. J. Hidrolitan. Vol.2 (1): 31-39.

Destiana, I.D., Darmawati, E. dan Nugroho, L.P.E. 2016. Pengaruh beberapa kemasan plastik terhadap kualitas benih kedelai selama penyimpanan. Vol. 4 (1): 45-52. JTEP (Jurnal Keteknikan Pertanian). IPB Bogor

Dinarto, W. 2010. Pengaruh kadar air dan wadah simpan terhadap viabilitas benih kacang hijau dan populasi hama kumbang bubuk kacang hijau Callosobruchus Chinensis L. Vol. 1 (1): 68-77. Jurnal Agrisains. ISSN:2086-7719.

Hasanah, M., dan D. Rusmin. 2006. Teknologi 
Pengelolaan Benih Beberapa Tanaman Obat di Indonesia. Jurnal Litbang Pertanian: 25 (2): 68- 73 .

Karyudi dan Siagian, N. 2005. Peluang dan kendala dalam pengusahaan tanaman penutup tanah di perkebunan karet. Prosiding Lokakarya Nasional Tanaman Pakan Ternak. Puslitbangnak. Bogor. P: $25-33$.

Sadjad, S., Faiza, S., Suwarno dan Setia Hadi, 2001. Tiga Dekade Berindustri Benih di Indonesia. Grasindo, Jakarta.

Statistik perkebunan. 2015. Pusat data dan informasi pertanian. Departemen pertanian.

Sumarmaji. 1986. Kebutuhan dan masalah pengadaan benih penutup tanah kacangan di perkebunan. Balai Penelitian Perkebunan Sungei Putih.23 p.

Waluyo,N., Azmi, C., dan Kirana, R. 2014. Pengaruh jenis kemasan terhadap mutu fisiologis benih bawang daun selama periode simpan. Agrin. Vol:18(2):148-17 